\title{
Learning and Teaching in the Technological Era: Introduction to the IJELLO Special Series of Chais Conference 2011 Best Papers
}

\author{
Nitza Geri, Yoav Yair, Avner Caspi, Sigal Eden, \\ and Yoram Eshet-Alkalai \\ The Open University of Israel \\ Raanana, Israel
}

\section{nitzage@openu.ac.il ; yoavya@openu.ac.il; avnerca@openu.ac.il; sigaled@openu.ac.il; yorames@openu.ac.il}

\begin{abstract}
This is the third issue of Interdisciplinary Journal of E-Learning and Learning Objects (IJELLO) special series that is based on selected best papers presented at the Sixth Chais Conference on Instructional Technologies Research 2011: Learning in the Technological Era. The conference took place at The Open University of Israel, Raanana, Israel, on February 17, 2011, and was organized by its Research Center for Innovation in Learning Technologies.

This preface presents the mission and activities of the Research Center for Innovation in Learning Technologies at the Open University of Israel. It describes the objectives and themes of the Chais Conference 2011, explains its synergies with IJELLO and the Informing Science Institute, and introduces the papers included in this special issue. This paper collection emphasizes the importance of teachers' training, and reflects the growing understanding of their major role in integrating innovative technologies in education.
\end{abstract}

Keywords: instructional technologies, e-learning, technology integration in education, diffusion of innovation, human-computer interaction, usability, collaborative learning.

\section{Introduction}

Innovative instructional and learning technologies are among the major forces that can improve knowledge dissemination, education, life-long learning, on-the job training, and subsequently welfare in the information era. The Open University of Israel (OUI) is based on distance and blended learning and, thus, is committed to the ongoing examination and improvement of its teaching quality through the integration of innovative learning and teaching technologies. The Research Center for Innovation in Learning Technologies functions as the infrastructure and

Material published as part of this publication, either on-line or in print, is copyrighted by the Informing Science Institute. Permission to make digital or paper copy of part or all of these works for personal or classroom use is granted without fee provided that the copies are not made or distributed for profit or commercial advantage AND that copies 1) bear this notice in full and 2) give the full citation on the first page. It is permissible to abstract these works so long as credit is given. To copy in all other cases or to republish or to post on a server or to redistribute to lists requires specific permission and payment of a fee. Contact Publisher@InformingScience.org to request redistribution permission. mechanism research arm of the Open University for exploring emerging technologies and developing models and strategies for their integration in learning. The main objective of the Center is to promote research related to the enhancement of instruction, using innovative learning technologies. The Center consists of a consortium of about 40 faculty members from the various OUI departments. The Center conducts a 
large variety of ongoing academic activities such as symposia, workshops, conferences and research seminars.

The following are some of the fields of research in which the Research Center for Innovation in Learning Technologies engages in:

- The theoretical foundations of learning, instructional technology and distance education.

- Integration of innovative information and communication technologies into educational systems.

- Defining and characterizing the variables needed for developing flexible and adaptive technology-enhanced instructional strategies that respond to students' individual needs.

- Studying the pedagogical and cognitive contributions of emerging technologies to teaching and learning.

"Learning in the Technological Era" is a series of annual national research conferences on learning technologies initiated in 2006 by the Chais Research Center in collaboration with EDEN, The European Distance and E-Learning Network. The Research Center for Innovation in Learning Technologies is committed to continue this important research activity, under the name of Chais conference, which commemorates the contribution of the late Stanley Chais, who funded the establishment of the Chais Center. The Chais conference contributes to the formation of a community of Israeli researchers in the field of instructional technologies and to the positioning of the Open University of Israel as a leading organization in the study and implementation of learning technologies. About 500 researchers from most universities and academic colleges in Israel and from many organizations and Information Technology (IT) companies participate in the conference each year.

The purpose of this IJELLO special series of Chais conference best papers is to enhance the international impact of the Chais conference by distributing high quality papers from the local conference to worldwide audience. The Informing Science Institute (ISI) is a natural partner for this mission because it draws together researchers and practitioners of information technologies, who seek effective ways to inform clients about sharing their knowledge with others (http://www.informingscience.org/). The informing science transdiscipline studies the informing process, defined as providing a specific clientele with information in a form, format, and schedule that maximizes its effectiveness (Cohen, 1999, 2009; Gill \& Cohen, 2009). Instructional technologies are a certain type of information technologies that aim at providing students and other learners with information and tools to enhance their learning. Within the ISI journals, the Interdisciplinary Journal of E-Learning and Learning Objects publishes high quality articles on theory, practice, innovation, and research that cover all aspects of E-learning and Learning Objects (http://www.ijello.org).

The first issue of this series was published two years ago and included 13 selected papers, which dealt with various aspects of technology integration in teaching and learning, collaborative learning environments, quality of mobile learning, motivation for technology use, and more (EshetAlkalai, Caspi, Eden, Geri, \& Yair, 2009). The second issue, which includes the best papers of Chais conference 2010, was published last year, with nine papers, on the topics of integration of technology in education systems, diffusion of innovation in learning environments, mobile culture, school versus home learning, collaborative learning, and social aspects (Eshet-Alkalai, Caspi, Eden, Geri, \& Yair, 2010). This third issue of Chais conference 2011 best papers emphasizes the role of teachers in integrating innovative instructional technologies. 


\section{Chais Conference 2011 Best Papers}

Out of 64 short papers that were submitted to the 2011 Chais conference and underwent a blind peer-review process, 42 papers and nine posters were presented at the conference and were included in the conference's proceedings volume (Eshet-Alkalai, Caspi, Eden, Geri, \& Yair, 2011). This third issue of the IJELLO Special Series of Chais Conference Best Papers includes nine of the most outstanding Chais Conference 2011 papers, which were expanded and modified for publication in IJELLO and have undergone a full review process by the IJELLO editors and reviewers.

The first paper by Eran Gal and Rafi Nachmias ("Implementing online learning and performance support using an EPSS") assessed the effectiveness of Electronic Performance Support Systems (EPSS) for both learning and performance support. This study was conducted in a large telecommunications company, and the participants were 276 service representatives. Their findings indicated that EPSS effectiveness is highly dependent on organizational environments and user experience. Their conclusions may help in formulating development and implementation guidelines for both learning and performance support personnel by matching EPSS strategies to users' attributes and organizational environments.

Nitza Geri ("If we build it, will they come? Adoption of online video-based distance learning") examined the adoption of interactive online video-based distance learning. The results, based on analysis of about 19,000 actual enrollment decisions of students in two introductory courses at the Open University of Israel, indicated that only $7 \%$ of these decisions were to take the video-based study group. A comparison of 222 overseas students indicated that video lectures have not significantly improved their perseverance and achievements in these introductory courses. Clearly, the influence of video lectures on student achievements should be further studied.

Galit Ben-Zadok, Moshe Leiba, and Rafi Nachmias ("Drills, games or tests? Evaluating students' motivation in different online learning activities, using log file analysis") compared students' behaviors in three types of learning activities, drills, games, and self-tests, in order to explore students' motivation to learn in each one of them. They analyzed the actions of 7,434 students in $3^{\text {rd }}-$ $6^{\text {th }}$ grades, and their results imply that drills and self-tests served more than games as motivating tools for learning. They emphasize the importance of identifying the conditions under which online activities increase student motivation and support learning processes.

The above three papers focused on the learners. The fourth paper by Edith Manny-Ikan, Osnat Dagan, Tal Berger-Tikochinski, and Rachel Zorman ("Using the Interactive White Board in teaching and learning - An evaluation of the SMART CLASSROOM Pilot Project") examined the effects of the introduction of Interactive White Board (IWB) and related technologies in class on teachers, students, and the school community. Their findings indicated both increase in student motivation and engagement in the learning process, as well as in teachers' professional development and technology skills. However, they reported some difficulties and challenges, such as a sense of over-burdening among teachers. Manny-Ikan et al. conclude that there is a need to focus on the pedagogical training of the teachers, and, in order to help relieve the over-burdening of teachers, a database of instructional tools should be established providing suggestions for lesson plans and instructional materials.

The next five papers in this special issue focus on the teachers and address some of the issues raised by Manny-Ikan et al., along with other aspects of teaching in the technological era.

Ina Blau ("Teachers for "Smart Classrooms": The extent of implementation of an interactive Whiteboard-based professional development program on elementary teachers' instructional practices") assessed to what extent teachers, who participated in an IWB professional development program, implemented IWB-related strategies (such as technology-pedagogy correspondence, 
interactivity types, teaching-learning mode, differentiated learning, student-centered learning, and multimedia principles) in their instructional practices. The results are discussed in terms of constructivist and cognitive approaches to teaching and learning.

Orit Avidov-Ungar and Yoram Eshet-Alkalai ("Teachers in a world of change: Teachers' knowledge and attitudes towards the implementation of innovative technologies in schools") explored teachers' perceptions and attitudes towards implementation of a smart classroom. Data was collected from 100 teachers, by questionnaires that captured their level of "Technological Pedagogical Content Knowledge" (TPACK), their perception of school as a learning organization, and their attitude towards change. Their findings indicated positive correlations between these constructs.

Miri Barak, Yael Nissim, and Dani Ben-Zvi ("Aptness between teaching roles and teaching strategies in ICT-integrated science lessons") examined qualitatively how teachers' perceptions about their roles may serve to support or oppose the integration of new practices while using information and communication technologies (ICT). Their findings indicated that in the ICT lessons teachers mainly acted as guides and motivators while applying two teaching strategies: visualization and problem-solving. They demonstrate how their suggested aptness matrix can help teachers identify their own level of ICT implementation while promoting constructivist teaching and learning in their classrooms.

The last two papers deal with two opposing types of collaboration among teachers in developing study materials and address the above-mentioned need to relieve the over-burdening of teachers, by providing them with repositories of instructional materials and open educational resources (OERs) fit for the contemporary class environment.

Anat Cohen, Eli Shmueli, and Rafi Nachmias ("The usage of data repositories: the case of MAOR") analyzed the MAOR (Meta-data and Object Repository) repository, which is a national Israeli repository of online learning object meta-data, containing materials for both K-12 and higher education and enabling teachers to share, reuse, and remix modular learning objects. They describe the MAOR repository and the stages of its establishment and analyze its growth. Although MOAR was established based on the MERLOT model, its contributors' profile is different and most of the contributors are the authors. The findings also show a distinction in the contribution rates between those institutions that consider contribution of materials as part of their policy and institutions that do not.

Atara Shriki and Nitsa Movshovitz-Hadar ("Nurturing a community of practice through a collaborative design of lesson plans on a Wiki system") examined the processes involved in a collaborative effort of 11 graduate students, experienced mathematics teachers, who participated in a semester long activity in which they designed and developed lesson plans on a Media Wiki system. Evidently, the participants quickly evolved into a small and very Wiki-active community of practice. The results indicate that this community was concerned with social issues related to the teachers' consideration as to how to provide and receive feedback, as well as uncertainty about the possibility of losing the ownership over their creative work.

The above papers represent the main themes of the Chais 2011 conference. Other themes that were presented at the conference but were not covered in this special issue included: Technology in the service of people with special needs; Parents and children on the net; Educational-social interaction on the internet and Cognitive aspects of working in learning environments.

\section{Conclusion and Acknowledgements}

This third issue of IJELLO special series of Chais conference best papers, entitled "learning and teaching in the technological era" reflects the shift towards teachers' training, and the growing 
understanding of their major role in integrating innovative instructional technologies. We hope these papers will be of interest to the readers and will encourage future innovative and synergetic instructional technologies research. We look forward to the IJELLO next issue of the best papers of Chais conference 2012, which is scheduled for February 15-16, 2012, at the Open University of Israel campus in Raanana, Israel.

We would like to express our ongoing gratitude to Alex Koohang, the Editor-in-Chief of the Interdisciplinary Journal of E-Learning and Learning Objects, for his enthusiastic support and encouragement and for conducting this editorial effort. On behalf of the authors, we also thank him for his constructive guidance.

Many thanks to Eli Cohen and Betty Boyd of the Informing Science Institute for enabling the production of this special series. Special thanks to Betty Boyd for the publishing work and for helping the authors with the presentation of their work.

Thanks to all the contributing authors and reviewers for their excellent work. Finally, we would like to thank the community of Israeli instructional technologies researchers and practitioners for participating in Chais conferences and contributing to the development of this important field.

\section{References}

Cohen, E. (1999). Reconceptualizing information systems as a field of the transdiscipline informing science: From ugly duckling to swan, Journal of Computing and Information Technology, 7(3), 213-219.

Cohen, E. (2009). A philosophy of informing science. Informing Science: the International Journal of an Emerging Transdiscipline, 12, 1-15. Retrieved from http://inform.nu/Articles/Vol12/ISJv12p001015Cohen399.pdf

Eshet-Alkalai, Y., Caspi, A., Eden, S., Geri, N., \& Yair, Y. (2009). Introduction to the IJELLO special series of Chais Conference 2009 best papers. Interdisciplinary Journal of E-Learning and Learning Objects, 5, 181-186. Available at: http://ijello.org/Volume5/IJELLOv5p181-186ChaisPreface.pdf

Eshet-Alkalai, Y., Caspi, A., Eden, S., Geri, N., \& Yair, Y. (2010). Challenges of integrating technologies for learning: Introduction to the IJELLO special series of Chais Conference 2010 best papers. Interdisciplinary Journal of E-Learning and Learning Objects, 6, 239-244. Available at: http://www.ijello.org/Volume6/IJELLOv6p239-244Intro.pdf

Eshet-Alkalai, Y., Caspi, A., Eden, S., Geri, N., \& Yair, Y. (Eds.) (2011). Proceedings of the Chais conference on instructional technologies research 2011: Learning in the technological era. Raanana: The Open University of Israel.

Gill, T. G., \& Cohen, E. (Eds.). (2009). Foundations of informing science, 1999-2008. Santa Rosa, CA: Informing Sciences Press.

\section{Biographies}

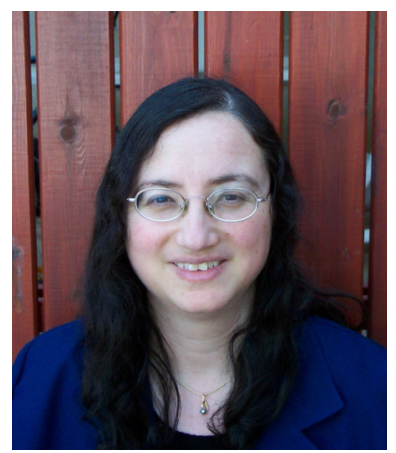

Nitza Geri is Head of the Department of Management and Economics, the Open University of Israel. She holds a B.A. in Accounting and Economics, an M.Sc. in Management Sciences and a Ph.D. in Technology and Information Systems Management from Tel-Aviv University. Nitza is a CPA (Israel) and prior to her academic career she had over 12 years of business experience. Her research interests and publications focus on various aspects of the value of information, and information systems adoption and implementation, including strategic information systems, e-business, value creation and the Theory of Constraints, managerial aspects of e-learning systems adoption and use. Personal site: http://www.openu.ac.il/Personal sites/nitza-geri.html 


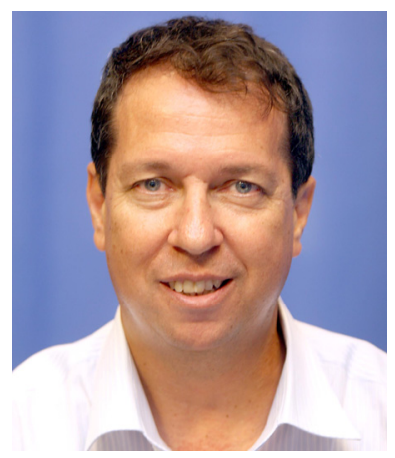

Yoav Yair is Dean of Development and Educational Technology at the Open University of Israel. He is a faculty member at the Open University, Department of Life and Natural Sciences. He is an expert on educational technology, having worked as software designer and educational program developer at the Centre for Educational Technology (CET) in Tel-Aviv for 15 years. His main interests in this field are scientific visualization and desktop virtual reality. He also wrote 4 textbooks for the K-12 Israeli education system and was a chief software designer of several educational software and websites. At the Open University of Israel, in the years 2004-2009, Prof. Yair headed the Center for Technology in Distance Education (SHOAM), tasked with developing, testing, disseminating and evaluating learning technologies for usage in distance education. In this capacity he was responsible for introducing new technologies into the Open University, with emphasis on the academic usage of the OPUS Hebrew-based learning management system, of video broadcasts and synchronous voice-over-IP systems, as well as collaborative tools such as Wikis. Prof. Yair leads the Open Courseware project at the Open University of Israel, with a new initiative to open complete e-books and audio-books on-line for free usage by the general public. Prof. Yair published numerous papers in atmospheric sciences and on the usage of technology in science and distance education. He now leads new projects in mobile e-books for academic courses. Prof. Yair is an atmospheric and space physicist and leads a research team for studying thunderstorms, lightning and their effects on the atmosphere. Another field of research is science education with emphasis on Astronomy and the Earth Sciences. Personal site:

http://www.openu.ac.il/Personal_sites/yoav-yair.html

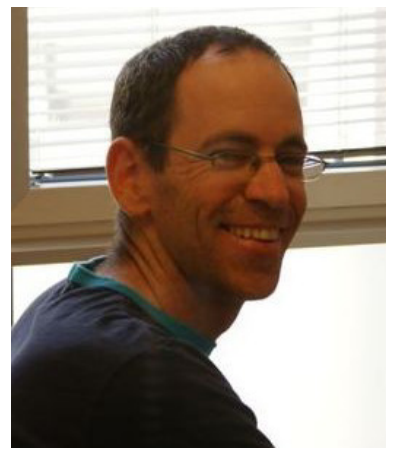

Avner Caspi is a faculty member at the Open University of Israel, Department of Education \& Psychology. He holds a B.A. in Behavioral Sciences (Tel-Aviv Yaffo Academic College), and Ph.D. in Cognitive Psychology (Tel Aviv University). His major research and publications interests focus on social aspects of communication technologies, mainly in the area of learning and instruction. Personal site: http://www.openu.ac.il/Personal_sites/avner-caspi.html

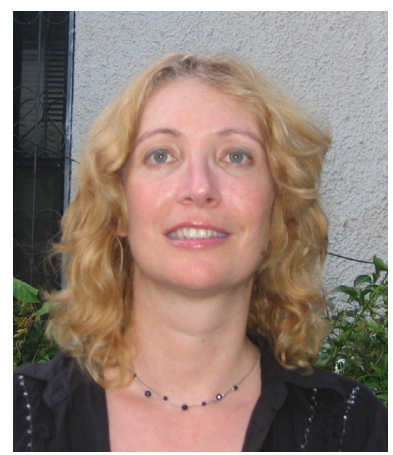

Sigal Eden is a fellow researcher and a member of the Research Center for Innovation in Learning Technologies, the Open University of Israel, and a lecturer of Bar Ilan University, School of Education. She holds a B.A. in Education for Students with Hearing Impairment from Tel-Aviv University, an M.A. and Ph.D. in Educational Technologies from Bar-Ilan University. Her research interests and publications focus on various aspects of working with digital environments, especially the enhancement of cognitive and linguistic aspects among people with special needs. Personal site: http://www.openu.ac.il/research_center_eng/Sigal_Eden_card_E.html 


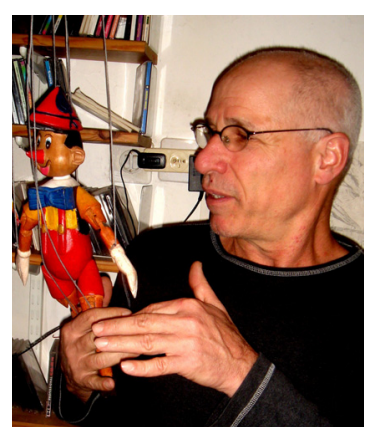

Yoram Eshet-Alkalay is a faculty member at the Open University of Israel, Department of Education \& Psychology. He is the Coordinator of the M.A. program in educational technology and the Head of the Research Center for Innovation in Learning Technologies in the Open University. He holds a B.A. in Archeology (Hebrew University), M.Sc. in Geology (Hebrew University) and Ph.D. in Earth \& Environmental Sciences (City University of NY). For a decade, he was the Head of the Instructional Design Program in the Tel Hai Academic College, and a senior researcher in the Geological Survey of Israel. He has 15 years experience in developing technology-based instructional solutions for educational systems in Israel and the USA. In this capacity, he was involved in the design of hundreds of simulations, data-bases, tutorials and large-scale curriculum integration projects. His major research and publications interests focus on cognitive aspects of working with digital technologies, digital games and design principles of computer-based learning environments. Personal site: http://www.openu.ac.il/Personal_sites/yoram-eshet.html 